\title{
Koronapandemien har gitt oss mange etiske utfordringer
}

Under hele pandemien har hensynet til den enkelte blitt veid opp mot hensynet til fellesskapet. Har prioriteringene vært riktige, eller har de vært drevet av frykt?

\section{Anne Kari Tolo Heggestad}

Professor

Fakultet for helsefag, VID vitenskapelige høgskole

\begin{tabular}{llll}
\hline Etikk Helsepersonell & Prioriteringer \\
\hline
\end{tabular}

\section{Hovedbudskap}

Under pandemien har vi opplevd mange etiske utfordringer. Utfordringene har blant annet handlet om prioritering av utstyr og helsehjelp, bes $\varnothing$ ksstans og ivaretakelse av døende. I denne etikkspalten reflekterer jeg over hvordan disse utfordringene ble håndtert, og over hvorvidt vi kunne håndtert dem på en bedre måte. Det de ansatte har stått i under pandemien, mener jeg er underkommunisert og noe vi trenger forskning på.

Etter et og et halvt år med et liv og et samfunn «på vent» er vi endelig på vei tilbake til det normale. Selv om pandemien ikke er over ennå, kan vi se tilbake på hva vi har lært, og hva vi kan ta med oss videre. 
Når det gjelder etikk og etiske utfordringer, har vi lært noe om hvilke verdier som utfordres under en pandemi. I etikkspalten våren 2020 skrev jeg om hvilke verdier som vi opplevde ble satt på prøve i starten av pandemien (1).

\section{«De utfordringene vi trodde ble de største, ble ikke så store som vi hadde fryktet.»}

I den første fasen ble spesielt prioriteringsutfordringer tydelige. Det handlet om alt fra prioritering av utstyr til prioritering av helsehjelp. En studie som ble gjennomført ved sykehus i Norge våren 2020, bekreftet disse utfordringene (2).

Etter hvert oppsto andre utfordringer som var knyttet til smittevern og bes $\varnothing \mathrm{k}$ på sykehjem, behandling av sykehjemsbeboere og døende samt fordeling av vaksiner $(3,4)$. Det som er interessant, er at de utfordringene vi trodde ble de største, slik som press på intensivplasser og mangel på respiratorer, ikke ble så store som vi hadde fryktet.

\section{Gikk frykten ut over fordelingen av ressurser?}

I ettertid kan vi spørre oss om ikke håndteringen og prioriteringene i starten av pandemien var panikk- og fryktdrevet, slik at ressursfordelingen dermed ble feil. Fikk oppmerksomheten på intensivplasser og sykehuskapasitet for stor plass, slik at kommunehelsetjenesten fikk lide? Vi var flere som var bekymret for dette $(3,5)$. Samtidig må vi ta $\mathrm{i}$ betraktning at covid-19 var en helt ny sykdom, som vi hadde lite kunnskap om og få erfaringer å bygge på.

En annen ting vi bør spørre oss om, er om vi i for stor grad vektla smittevern, spesielt på sykehjem. Når vi står overfor etiske utfordringer, er det ofte ulike verdier som kommer i konflikt. Og da må vi velge hvilke verdier vi vil prioritere. 
Under pandemien kunne det se ut som om verdien av liv og helse trumfet verdier knyttet til de psykososiale behovene. En slik prioritering er ikke ny. Forskning har også vist tidligere at medisinske og fysiske behov ofte blir prioritert fremfor de psykososiale behovene $(6,7)$.

\section{«Når vi står overfor etiske utfordringer, er det ofte ulike verdier som kommer i konflikt.»}

Vi kan jo spørre oss om de eldste på sykehjem ville hatt det bedre hvis de hadde fătt mer bes $\varnothing \mathrm{k}$, og vi hadde lagt mindre vekt på smittevern? Samtidig har det vært ekstra utfordrende på sykehjem når hensynet til den enkelte beboerens behov for sosial kontakt ble satt opp mot fellesskapets behov for smittevern.

Selv om en beboer på et sykehjem kanskje ville vært mer opptatt av å få bes $\varnothing \mathrm{k}$ av sine nærmeste enn å beskytte seg selv mot smitte, måtte man likevel ta hensyn til fellesskapet og de som var redd for å bli smittet. Hensynet til den enkelte veid opp mot hensynet til de andre har vært et etisk dilemma gjennom hele pandemien.

Under pandemien har vi lært mye om hvordan vi både kan legge til rette for bes $\varnothing \mathrm{k}$ samt ivareta smittevern. Vi måtte være kreative og finne nye løsninger, med digitale møteplasser og fysiske møteplasser utenfor institusjonene. Denne lærdommen kan vi ta med oss videre.

\section{Hvordan har redselen påvirket de ansatte?}

En problemstilling det ikke har vært snakket så mye om, er de ansatte i helsetjenesten med tanke på det de har ofret, og den risikoen de har tatt. Mange har kjent på en frykt for å ta med seg smitte til pasienter, men også for å ta med seg smitte hjem. 
Vi vet lite om hvordan denne redselen har påvirket de ansatte, og hvilke konsekvenser den har fått $\mathrm{i}$ etterkant. Vi vet lite om hvilket moralsk stress de ansatte har opplevd, og om dette stresset kan ha ført til større utskiftning av ansatte. Her trengs det forskning.

\section{«Vi vet lite om hvilket moralsk stress de ansatte har opplevd.»}

Utfordringene som er beskrevet over, er ikke nye. Slike utfordringer står vi overfor i helsetjenesten hver dag. Men vi har sett at utfordringene har blitt forsterket under pandemien, og de har hatt større konsekvenser både for pasienter og ansatte.

Nå må vi ikke slutte å sette søkelyset på problemstillingene, selv om de er mindre dramatiske enn de har vært under pandemien. Vi må fortsette å spørre oss om vi prioriterer riktig, og vi må fortsette å stille spørsmål om vi ivaretar døende på en verdig måte. Vi må ta de ansattes moralske stress på alvor, uavhengig av om vi står i en pandemi eller ikke.

\section{Referanser}

1. Heggestad AKT. I krevende tider blir verdiene våre satt på prøve. Sykepleien. 2020;108(80878):(e20878). DOI: $\underline{10.4220 / \text { Sykepleiens.2020.80878 }}$

2. Miljeteig I, Forthun I, Hufthammer KO, Engelund IE, Schanche E, Hus $\varnothing y$ OK. Priority-setting dilemmas, moral distress and support experienced by nurses and physicians in the early phase of the COVID-19 pandemic in Norway. Nurs Ethics. 2021;28(1):66-81. DOI: 10.1177/0969733020981748

3. Myrstad M, Ranhoff AH. Akutt syke eldre i koronaens tid. Tidsskr Nor Legeforen. 25.03.2020. DOI: $10.4045 /$ tidsskr.20.0227 
4. Eriksen S, Grov EK, Lichtwarck B, Holmefoss I, Bøhn K, Myrstad C, et al. Behandling, omsorg og pleie for døende sykehjemspasienter med covid-19. Tidsskr Nor Legeforen. 23.04.2020. DOI:

10.4045/tidsskr.20.0306.

5. Heggestad AKT, Førde R, Pedersen R, Magelssen M. Prioriteringsutfordringer i helse- og omsorgstjenesten i kommunene under covid-19pandemien. Tidsskrift for omsorgsforskning. 2020;6(O1):1-4. DOI: 10.18261/issn.2387-5984-2020-01$\underline{11}$

6. Pedersen R, Nortvedt P, Nordhaug M, Sletteb $\varnothing$ $\AA$, Grøthe KH, Brinchmann BS, et al. In quest of justice? Clinical prioritisation in healthcare for the aged. J Med Ethics. 2008;34(4):230-5. DOI:

10.1136/jme.2006.018531

7. Heggestad AKT, Nortvedt P, Sletteb $\varnothing$ Å. Dignity and care for people with dementia living in nursing homes. Dementia. 2015;14(6):825-41. DOI:

$\underline{10.1177 / 1471301213512840}$ 